it a peptone beef broth emulsion of this mould and its spores. I found the best method of producing this emulsion was to pour a tube of the broth into a glycerine-agar culture of the mould, the culture being 15 days old, and then to scrape off as much of the mould and its spores as possible with a stout, sterile, platinum spatula. The flasks thus inoculated were then plugged and the whole of the neck was covered with gutta-percha tissue. A control flask was made in a similar manner and they were then incubated for 24 hours at $37^{\circ} \mathrm{O}$. On opening the flasks at the end of 24 or 48 hours, even 0.000001 gramme of arsenic reveals itself by a distinct smell of garlic, which seems to increase for the first 48 hours and then gradually to diminish, till after the fifth or sixth day it is imperceptible, the time of its continuance varying according to the amount of arsenic present By this means $I$ was able to detect in wall-papers a very small quantity of arsenic, confirming the mould test by Marsh's test. In cases where Marsh's test showed a wall. paper to contain less than $\frac{1}{20}$ th of a grain of arsenic per square foot the garlic smell was produced. Unfortunately, however, in this experiment the result was not always constant, for on repeating the experiment it was found that in some instances where a certain wall-paper had given the characteristic smell it failed to do so on a second occasion and vice versê.

My experiments with arsenic in beer were not so successful, owing partly to the fact that in order to induce the mould to grow the beer had to be neutralised with caustic soda and sweetened with cane sugar before it was poured into the flasks, and partly to the fact that the garlic smell produced by small quantities of arsenic was overpowered by the smell of the beer itself, such small quantities as $\frac{1}{20}$ th or $\frac{1}{30}$ th of a grain per gallon of beer being quite undistinguishable. As $\frac{1}{25}$ th of a grain of arsenic per gallon of beer is considered a dangerous amount ${ }^{3}$ this test is not suited for detecting the presence of arsenic in beer. It might be used as a preliminary test for the invert sugar sometimes used in brewing, but in any case, being a qualitative and not a quantitative test, it is of little practical value. By Reinsch's test Sheridan Delépine was able to demonstrate one part of arsenious acid in 10,000,000 parts of beer. ${ }^{4}$ The limit of demonstrating with any certainty the quantity of arsenic in beer by means of the penicilliam brevicaule test I have found to be 1 in 10,000 parts of beer.

As to the biological method of producing this gas, it remains still a matter of uncertainty. It was suggested to me by Dr. Allan Macfadyen that it might be due to the action of some enzymes present in the cell juices. To elucidate this I grew some penicillium brevicaule on saccharose broth at $37^{\circ} \mathrm{C}$., skimmed off two grammes, and washed it well in water till the latter came off quite clear. Then so as very thoroughly to express the juices both from the mycelium and the spores I made use of Macfadyen and Rowland's liquid air grinder, such as they use for grinding microorganisms in order to express their intracellular contents. This grinder consists of a metal pestle the under surface of which is roughened and which fits accurately into a metal mortar or pot. The pestle is then kept revolving and at the same time elevated and depressed alternately by means of a mechanical arrangement. During the process of grinding the pestle and mortar are kept immersed in liquid air. This intense cold, about $-190^{\circ} \mathrm{C}$., serves the double purpose of preventing chemical change during the grinding and at the same time of rendering the substance to be ground excessively brittle. By this method such small things as the typhoid bacilli themselves can be disintegrated en masse and reduced to an amorphous pulp, as seen under the microscope.

Having, then, as I said, introduced two grammes of the washed mould into the grinder, the material was ground at the temperature of liquid air for two and a half hours, at the end of which time when some of the pulp was placed under the microscope there was found to be no trace left of either mycelium or spores. Some of this pulp was then, whilst still frozen, dropped into tubes containing various solutions of sodium arsenite and arsenious acid, but no smell of garlic was produced, either at once or after 24 hours' incubation at $37^{\circ} \mathrm{O}$. This negative result was obtained both in the case of very young cultures of the mould and old sporing growths when treated in the same way. To ascertain, moreover, whether any enzymes had been given off into the saccharose 3 Occurrence of Arsenic in Sugars, Malt, and Beer, by B. E. R.
Newlands and Arthur R. Ling, Journal of the Institute of Brewers, 1901

4 Arsenic in Modern Life, Journal of Sanitary Institute, October, 1902. broth on which the penicillium brevicaule had been grown, various quantities of filtered broth were added to tubes containing arsenical solutions in the same manner as previously described, but in this case, too, no smell of garlic was produced, either at once or after 24 hours' incubation at $37^{\circ} \mathrm{C}$. It is therefore possible that Albert Maassen is correct in saying ${ }^{\bar{x}}$ that "the reducing property of the cells of animals and microbes is due to the presence of a substance which can exercise this power even when removed from the tissues, but the formation of methyl or ethyl derivatives seems to be really dependent on vital processes occurring only in the organism."

As regards the practical value of this penicillium brevicaule test for arsenic it has three great drawbacks: (1) that it is not a quantitative test ; (2) that the smell of garlic is liable to be overpowered by the smell of the substance tested ; and (3) that it is not constant in its results; in fact, this test is rather a biological curiosity than a reliable test for arsenic, to judge from the experiments which $I$ have been enabled to carry out.

\section{THE ORTOL REACTION AS A MEANS OF DISTINGUISHING RAW MILK FROM BOILED.}

By CARSTAIRS C. DOUGLAS, M.D., B.So., F.R.S. Edin., F.F.P.S. GLASG.,

PROFESSOR OF MEDICAL JURISPRUDENCE AND HYGIENE, ANDERSON'S COLLEGE MEDICAL SCHOOL, AND DIRECTOR OF THE WEST

OF SCOTLAND CLINIOAL RESEARCH IABORATORY, GLASGOW.

A COLOUR reaction which is of some interest and which is suggested as a means of distinguishing raw milk from boiled was described by Dr. J. E. Saul in a recent number of the British Medical Journal." Having looked into the matter a little and having performed the test in a large number of varying circumstances it has occurred to me that a brief note on the matter may not be amiss.

The test is simplicity itself. To perform it a few drops of a 1 per cent. solution of the organic compound orthomethyl-amino-phenyl-sulphate are added to raw milk or to milk which has not been raised above a certain temperature; this is followed by the addition of a drop of weak peroxide of hydrogen (five-volume strength) when, within a very short time-usually less than half a minute-a very deep reddishpink colour develops throughout the fluid. The reaction is singularly striking. When the same procedure is carried out with milk that has been boiled, though but for one minute, no change in colour is seen or at most the production of a faint brown tint. Dr. Saul in his paper describes this as a means of differentiating "raw" from "sterilised" milk, but this is somewhat misleading. What most medical men and practically all the laity understand by "sterilised" milk means milk raised to a temperature of $70^{\circ} \mathrm{C} .\left(158^{\circ} \mathrm{F}\right.$ ) and kept at this for a period of 30 minutes, more or less-a process often designated by the special term of "pasteurisation." Such milk, however, reacts readily to the reagents, which therefore do not serve to distinguish raw milk from this pasteurised, or so-called "sterilised," milk, but only from milk raised to a higher temperature than that at which pasteurisation is usually carried on. This temperature I find to be $75^{\circ} \mathrm{O}$. as a minimum. The following short table will show how the reaction is lost as the temperature rises :-

$$
\begin{aligned}
& \text { Milk kept for } 20 \text { minutes at } 70 \cdot 0^{\circ} \mathrm{C} \text {. reacted strongly. } \\
& \text { " " "15 , , } 74 \cdot 0^{\circ} \mathrm{C} \text {, feebly. } \\
& \text { " " } 5 \text { " }, 750^{\circ} \mathrm{C} \text {, ", negatively. }
\end{aligned}
$$

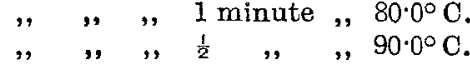

$$
\begin{aligned}
& \text { " " " " } \quad \frac{1}{4} \text { ", ", } 99.5^{\circ} \mathrm{C} . *, \text {," }
\end{aligned}
$$

It would appear, therefore, that it is at about $75^{\circ} \mathrm{C}$, that the reaction ceases to be given. The addition of acids, even the strong mineral acids, does not discharge or alter the colour to any extent, but alkalies convert it into a pale café au lait tint. Sour milk reacts as well as fresh.

As the compound ortho-methyl-amino-phenyl-sulphate is difficult to procure, Dr. Saul advises the use of "ortol"

5 Chemisches Centralblatt, 1902, pp. 1245-46. 1 Brit. Med. Jour., March 21st, 1903. 
instead-a substance used by photographers and consisting of the above body mixed with quinol. I have always employed it and I have for the sake of brevity ventured to call the test the "ortol reaction." Ortol is a finely granular powder of a pale flesh tint and the test can readily be performed by adding to five cubic centimetres of milk in a test tube a few granules of the powder and then a drop or two of solution of peroxide of hydrogen (from five to ten volumes) or what I find answers equally well, a similar amount of ozonic ether as employed in the guaiac test for blood. Dr. Saul suggests that the reaction is lost, not by any change in the ordinary chemical constituents of milk (proteid, sugar, fat, and salts), but by the destruction of some ferment or enzyme which possesses oxidising powers and which is rendered functionless at a high temperature just as many of the digestive ferments are. In support of this view I may cite the fact that I find fresh saliva acts in a similar way to raw milk, whereas, if boiled first, the reaction is lost. Fresh blood has only the faintest effect in developing a colour, whereas liquor pepticus, liquor pancreaticus, and malt diastase all share the property of raw milk and fresh saliva, though in a less active degree. In the case of human milk a colour change is also produced though not so rapidly sometimes as in cow's milk.

The reaction is not the only one recommended as a means of distinguishing between raw and boiled milk. In the April number of the Annales d'Hygiène Publique et de Médecino Légale, Ledé describes another method based on the loss of oxygen while milk is boiled. In this test a little peroxide of hydrogen is added to the milk in question and if the latter has been boiled the oxygen is taken up at once from the peroxide, whereas if it has not been boiled (and thus still contains its normal oxygen) it will now have a superfluity of the gas and the presence of this excess is demonstrated by the effect produced on a starch-potassium-iodide mixture. Another test is that proposed by Schardincer ${ }^{2}$ and based on the fact that fresh milk warmed to from $40^{\circ}$ to $45^{\circ} \mathrm{C}$. with a methylene-formalin-blue solution discharges the colour, while with a boiled milk the blue tint is retained.

Glasgow.

\section{Olinital 跑otes:}

\section{MEDICAL, SURGICAL, OBSTETRICAL, AND THERAPEUTICAL.}

\section{A NOTE ON SYPHILITIC RHEUMATOID AFFECTIONS. ${ }^{3}$} By Docent G. Singer.

SYPHILITIC rheumatoid affections often appear in the eruptive stage of the disease but still more frequently in the tertiary stage. According to Baumler they are characterised by remittent fever and by their tendency to get better under treatment with potassium iodide. But remittent fever is also peculiar to pyæmic forms of rheumatism and other diseases besides syphilis are benefited by the iodides. Of five cases of syphilitic rheumatoid disease which have come under my observation in the past three years four occurred in the tertiary stage and of these four one was complicated with myositis and osteo-periostitis.

The diagnosis of such cases is not easy. They are marked by arthritis, capsular swelling and thickening, and by periostitis which may last for years without causing any very serious functional troubles, this being the contrary to what occurs in other rheumatic inflammatory processes. Syphilitic rheumatic affections are not so painful as ordinary rheumatic affections and fever is often absent. Specific treatment gives good results even after the disease has lasted for many years.

The syphilitic nature of these processes, which may pass for cases of chronic rheumatism, may be suspected when there are present exostoses, abortion (in women), symptom of hereditary syphilis, progression of the disease without fever increased pain at night, and the very infrequent occurrence

2 Zeitschrift für Untersuchungen der Nahrungs- und GenussMittel, 1902.

3 Abstract of a paper read before the International Congress of Medicine at Madrid in April, 1903 or complete absence of any heart affection. Chronic arthritis, however, which arises from other causes such as gonorrhœea, may also give rise to a similar train of symptoms. Treatment by mercury or the iodides gives excellent results and the success of this treatment may be in general taken as a proof of the nature of the disease, although great success follows a similar method of treatment in cases of rheumatism arising from staphylococcic or streptococcic infection. It is recommended that all cases of rheumatism in which the etiology is doubtful should be treated with anti-syphilitic remedies.

Vienna.

\section{NOTE ON HYPERTROPHY OF ONE BREAST.}

Bx John R. Gibson, M.D., F.F.P.S. GLaSG.

RECENTLY I attended a young woman, 22 years of age, in her first confinement, which passed off satisfactorily. When putting on the bandage I was struck by the great size of the left breast compared with that of the right which was of normal size. I got the following history. At puberty the left breast developed very much more quickly than the right, so much so that in a few months from the start of its growth her dressmaker had to insert a pad over the right one to make her bust symmetrical. It gave her no annoyance except from its weight. At the present time the right breast is a normally developed breast for a woman of her size and figure. The following are the measurements. The right breast measured horizontally from the base over the nipple $7 \frac{1}{2}$ inches and vertically $7 \frac{1}{2}$ inches, the circumference at the base being 15 inches. The corresponding measurements of the left breast were $16 \frac{1}{2}$ inches, $16 \frac{i}{2}$ inches, and 26 inches respectively. It will be seen from these measurements that the breasts per $s e$ are quite symmetrical.

Both breasts secreted milk, the larger one seeming to be especially active and from the feel appeared to be made up for the most part of glandular tissue ; the veins over it were also much enlarged. I am aware that hypertrophy of both breasts is not altogether rare, but I do not remember having read about or seen one breast only hypertrophied.

Paisley.

\section{A e}

$$
\text { OF }
$$

\section{HOSPITAL PRACTICE, BRITISH AND FOREIGN.}

Nulla autem est alia pro certo noscendi via, nisi quamplurimas et morborum et dissectionum historias, tum aliorum tum proprias collectas habere, et inter se comparare.-MongAGNI De Sed. et Caus. Morb., lib. iv., Proœmium.

\section{LONDON TEMPERANCE HOSPITAL.}

\section{A CASE OF COMPLETE SUPRAPUBIC PROSTATECTOMY.}

(Under the care of Sir WILLIAM J. CoLLINS.)

For the notes of the case we are indebted to Mr. J. S. Hosford, surgical registrar.

The patient, a man, aged 71 years, had suffered for several years from frequent micturition and difficulty in passing urine, and for the last two years had been dependent almost entirely on the catheter for relief. For the last 12 months he had suffered "agony" and he had latterly passed the catheter nearly every hour. His sleep was greatly disturbed and his bed was nearly always wet. His general health was otherwise not bad, though he had lost a great deal of flesh lately. Per rectum a very large prostate was felt; he suffered a good deal from constipation. A No. 8 coudé catheter was passed without much difficulty but with a good deal of pain and sometimes it drew blood. The urine was alkaline, turbid, and contained a little muco-pus but not much albumin and no sugar.

The patient was admitted to the London Temperance Hospital under the care of Sir William J. Collins on Jan. 24th, 1903, and on Feb. 12th, as the patient was clearly going downhill and was very much depressed, Sir William 